\title{
The Correlation between Organizational Culture, Transformational Leadership and Work Motivation to Work Satisfaction
}

\author{
Ida Ryanti, Soewarto Hadhienata, Hurip Danu Ismadi \\ Post Graduate Program, Universitas Pakuan Bogor, Indonesia
}

*Corresponding Author: Ida Ryanti, Post Graduate Program, Universitas Pakuan Bogor, Indonesia.

\begin{abstract}
This study aims to determine the relationship of independent variables: Organizational Culture, Transformational Leadership, and Work Motivation either individually or together with the dependent variable of Job Satisfaction. The selected sample is 249 people with criteria of lecturer of a private Islamic university in Jambi Province, Indonesia. This research uses Sequential Explanatory Design Mixed Method with quantitative method first then followed with the qualitative approach. This procedure is intended to produce more in-depth and comprehensive research. The result of this research concludes that: there is relationship of organizational culture with job satisfaction through regression equation $\hat{Y}=13,126+0,880 X$ 1 with $R 2=76,8 \%$, transformational leadership with job satisfaction through regression equation $\hat{Y}=24,857$ $+0,759 \times 2$ with $R 2=57,1 \%$, and work motivation with job satisfaction through regression equation $\hat{Y}=$ $28,384+0,747 \times 3$ with $R 2=55,6 \%$. Also, there is positive relation of organisation culture, transformational leadership and work motivation together with job satisfaction through regression equation $\hat{Y}$ $=0,623+0,650 X 1+0,149 X 2+0,205 X 3$ with $R 2=83,2 \%$ indicating there are other factors that also related positive with an increase in job satisfaction of $16.8 \%$.
\end{abstract}

Keywords: Teachers performance, organizational culture, transformational leadership, and work satisfaction.

\section{INTRODUCTION}

Education contributes enormously to the nation's progress and development of the country's character. Among the many national development agendas, education is one of the critical and strategic plans that demands positive attention from all parties, because education is one of the determinants of the nation's future progress. The development of education carried out by the government with the community is an effort to manifest one of the national ideals, namely to educate the life of the nation. Education is one form of human capital investment, which determines the quality of human resources of a country. If as a society successfully builds the foundations of national education well, it is expected to contribute to progress in other fields.

The role of the lecturer as a professional has four responsibilities. First, related to morals, lecturers are required to live, practice, and pass on Pancasila - the state ideology - to students and young generation. Second, related to education, lecturers can manage the educational process for students in the form of teaching, guidance and so on. Third, related to society, lecturers are required to improve the quality of community life, fostering unity, and participate in the process of national development, the region, and the surrounding community. Fourth, related to science, lecturers are required to advance science and technology, especially in the field of expertise.

The description above shows that the position of the lecturer is very central, has a very decisive role in academic activities, and people who know the most educational process on campus. Therefore, lecturers must get serious attention so that their functions and roles can be implemented maximally. Lecturers are part of the human resources owned by the organization (Higher Education) which is the most important factor in the team. Thus, every university should always improve the quality of its human resources to achieve the goals that have been set. Enhance the quality of human resources is strongly influenced by the job satisfaction received and perceived within the organization. Therefore, 
job satisfaction is one of the factors that support the achievement of an organization's success. Until now, job satisfaction is still an interesting and important issue to study because it is huge influence both for the benefit of individuals, organizations, and society. The satisfaction and dissatisfaction that the members feel for their work in a group is part of the dynamic team that will always be there.

In this case, the researcher will only discuss factors that have the relationship with job satisfaction of lecturer, that is organizational culture, transformational leadership, and work motivation, while other related factors are not discussed in this research.

\section{LITERATURE REVIEW}

Wexley and Yuki (2005) define job satisfaction as the way workers feel about their work. Job satisfaction is influenced by several aspects of work, including wages / salary, working conditions, supervision, coworkers, job material, job security, as well as the opportunity to move forward. Anoraga (2006) revealed that job satisfaction is a positive attitude concerning good adjustment of employees to the conditions and work situations, including wage issues, social conditions, physical conditions and psychological conditions.

Kreitner and Kinicki (2000) define job satisfaction as a practical or emotional response to various aspects of work. Job satisfaction theories include: equity theory, discrepancy theory, need fulfillment theory, social reference group theory, expectancy theory, and Herzberg's two-factor theory. The explanation of the method is expressed by Mangkunegara (2004) that a person's job satisfaction depends on whether he feels justice or not for a situation. Feelings of justice or injustice to a position are obtained by comparing himself with others who are in the same office as elsewhere. There are three elements of truth:

a) Input is something that employees perceive as a contribution to their work such as education, experience, and proficiency.

b) The output is something that employees view as a result of their work: salary, status, symbols, and rewards.

c) Comparison person is the ratio between self-input and the other person's input-outcome ratio. If the value of this comparison is felt fair enough, then a person will feel satisfied. If the comparison is balanced, it can lead to satisfaction and if the comparison is unbalanced and detrimental will cause dissatisfaction.

Understanding of organizational culture cannot be separated from the core concept of culture itself, which is one of the most widely used terminologies in the field of anthropology. Today, in its anthropological view, the idea of culture has evidently shifted meaning. Today culture is defined as the manifestation of the lives of every person and every group of individuals. Now culture is seen as something more dynamic, not something rigid and static. Culture is not defined as a noun, now more interpreted as a verb associated with human activities. Colquitt, Lepine, and Wesson declare "Organizational Culture as the shared social knowledge within the organization of the rules, norms, and values that shapes the attitudes and behaviors of its employee (2009). From here the question arises, what is culture?

Culture is one way of living together, a typical way of humans in adjusting to the natural environment and is a personal strategy in meeting the needs of his life. The word culture has many meanings, the culture of each person is different from others and culture will be difficult to explain conceptually and definitively when applied in the organization. Thus the structure includes also the cultural aspects embodied in the form of stories, legends of the successful business, values, symbols that are meaningful to every human being in the organization.

Regarding words or terms in the study of administration and management are often found some conditions that are similar to cultural understanding. Some of them are as follows:

1. "Behavioral observable behavior"(because it is always repeated), i.e., when people interact, as well as the language used and the rituals that surround human behavior.

2. The "norms" gradually evolved within the working group as typically developed a one-day rule for a single day of fair pay. 
3. "Dominant values are taken" by an organization, e.g., quality of production.

4. "Philosophy" which guides the organization's wisdom in dealing with workers and their customers.

5. The old game "rules" of the game are used as "binders" in which a beginner must learn to become an acceptable member.

6. "Feeling or climate" conveyed within an organization through the physical layout, and the way members interact with their subscriptions or other outside parties. (Edgar H. Schein, 2004).

Leadership has many different types or styles. Achieving the vision and goals of the organization is largely determined by the style of leadership. A leader, like a principal, has a great responsibility in the execution of a job. Success leads depending on his behavior whether he can influence, empower and stimulate his subordinates to synergize to realize the vision of the organization. Transformational leadership is one type or style of leadership that allegedly can affect the work satisfaction of his subordinates.

Bernard M. Bass \& Ronald E. Riggio (2006) defines transformational leadership as a behavior that stimulates and inspires followers to achieve results and in the process of developing leadership abilities, the vision and goals the organization provides, challenges itself to innovate, solve problems, and develop leadership skills to their subordinates through direction, mentoring, and providing challenges and support. "Transformational leaders, on the other hand, are managing their extraordinary outcomes and, in the process, developing their leadership capacity." The dimensions and indicators are described below:

1. The ideal effect dimension with indicators: 1) behavior and 2) nature.

2. Dimensions of motivation inspiration with the indicators: 1) excitement and 2) optimistic.

3. Dimensions of intellectual stimulation with the indicators: 1) innovative and 2) creative.

4. Dimensions of individual attention with the indicators: 1) achievement and 2) growth.

According Luthans, (2011) motivation is a process that begins with physiological or psychological deficiencies that drive behavior or encouragement intended for incentive purposes. The factors that showed motivation to work are: a) interact; b) each depending on the needs; c) support; d) incentives.

According to Gibson (2012) "motivation is forces acting on an employee that initiate and direct behavior. This concept explains differences in the intensity of action regarding more extreme behavior as the result of higher levels of motivation and also to indicate the direction of response. This concept suggests that behavior is more frequently manifested in increasing motivation. The factors that showed motivation to work are a) drive and b) directing action.

Based on the theories above, it can be synthesized that motivation is a force to encourage, stimulate and steer both from within and from outside to act and behave to achieve the stated goals of both individuals and organizations. The factors that showed work motivation based on the internal dimensions are: a) responsibilities; b) self-development; c) independence; d) attempt to meet the needs of the work, and the factors that showed motivation to work based on the external dimensions are: e) interpersonal relationships; f) collaborate with the hope to get incentives; g) work with the hope of getting the attention of superiors.

\section{Methodology}

This study applies Sequential Explanatory Design Mixed Method where quantitative research is ahead of the qualitative study to examine the relationship between variables tested in the survey using three independent variables through data obtained from questionnaires. The independent variable is Organizational Culture $\left(\mathrm{X}_{1}\right)$, Transformational Leadership $\left(\mathrm{X}_{2}\right)$, and Working Motivation $\left(\mathrm{X}_{3}\right)$, while the dependent variable is the Work Satisfaction (Y).

The population of this research is all lecturers of private Islamic universities in Jambi Province with the number of private Islamic universities as much as 16 and the number of permanent lecturers as much as 660 people. The sample in this research is representation from the lecturer of the private 
Islamic university in Jambi Province taken by proportional random sampling technique. The sample size is calculated using the Slovin formula obtaining 249 samples. Qualitative study for confirmation was performed through observation and interview to the key informant as well as conducting focus group discussion with lecturers.

\section{RESUlts AND DiscusSiON}

From the findings obtained in this quantitative research phase it can be seen that $83.5 \%$ job satisfaction is affected by organizational culture, transformational leadership and work motivation together, so it can also be estimated that $16.5 \%$ is contributed by the other related variables with the increase in job satisfaction either directly or indirectly.

Table 1. Summary of Research Hypotheses Testing Results.

\begin{tabular}{|c|c|c|c|c|c|c|c|}
\hline $\begin{array}{l}\mathrm{N} \\
\mathrm{O}\end{array}$ & $\begin{array}{c}\text { Hypothesis and Regression } \\
\text { Equation }\end{array}$ & $\begin{array}{l}\text { Statistical } \\
\text { test }\end{array}$ & Calculated F & Decision & Conclusion & $\mathrm{R}$ & $\mathrm{R}^{2}$ \\
\hline $\begin{array}{l}1 \\
.\end{array}$ & $\begin{array}{c}\text { Organizational Culture }\left(\mathrm{X}_{1}\right) \\
\text { positively affected Work } \\
\text { Satisfaction }(\mathrm{Y}) \\
\hat{\mathrm{Y}}=13.126+0.880 \mathrm{X}_{1}\end{array}$ & $\begin{array}{l}\mathrm{H}_{0}: \square_{\mathrm{y} 1} £ 0 \\
\mathrm{H}_{1}: \square_{\mathrm{y} 1}>0\end{array}$ & 817.644 & $\begin{array}{c}\mathrm{H}_{0} \\
\text { rejected }\end{array}$ & Significant & $\begin{array}{c}0.87 \\
6\end{array}$ & $\begin{array}{c}76.8 \\
\%\end{array}$ \\
\hline $\begin{array}{l}2 \\
.\end{array}$ & $\begin{array}{c}\text { Transformational Leadership } \\
\left(\mathrm{X}_{2}\right) \text { positively affected Work } \\
\text { Satisfaction }(\mathrm{Y}) \\
\hat{\mathrm{Y}}=24.857+0.759 \mathrm{X}_{2}\end{array}$ & $\begin{array}{l}\mathrm{H}_{0}: \square_{\mathrm{y} 2} £ 0 \\
\mathrm{H}_{1}: \square_{\mathrm{y} 2}>0\end{array}$ & 329.117 & $\begin{array}{c}\mathrm{H}_{0} \\
\text { rejected }\end{array}$ & Significant & $\begin{array}{c}0.75 \\
6\end{array}$ & $\begin{array}{c}57.1 \\
\%\end{array}$ \\
\hline $\begin{array}{l}3 \\
.\end{array}$ & $\begin{array}{c}\text { Work Motivation }\left(\mathrm{X}_{3}\right) \\
\text { positively affected Work } \\
\text { Satisfaction } \mathrm{Y}) \\
\hat{\mathrm{Y}}=28.384+0.747 \mathrm{X}_{3}\end{array}$ & $\begin{array}{l}\mathrm{H}_{0}: \square_{\mathrm{y} 3} £ 0 \\
\mathrm{H}_{1}: \square_{\mathrm{y} .3}>0\end{array}$ & 309.519 & $\begin{array}{c}\mathrm{H}_{0} \\
\text { rejected }\end{array}$ & Significant & $\begin{array}{c}0.74 \\
6\end{array}$ & $\begin{array}{c}55.6 \\
\%\end{array}$ \\
\hline $\begin{array}{l}4 \\
.\end{array}$ & $\begin{array}{c}\text { Organizational Culture }\left(\mathrm{X}_{1}\right) \text {. } \\
\text { Transformational Leadership } \\
\left(\mathrm{X}_{2}\right) \text { and Work Motivation } \\
\left(\mathrm{X}_{3}\right) \text { altogether positively } \\
\text { affected Work Satisfaction } \\
(\mathrm{Y}) \hat{\mathrm{Y}}=0.623+0.650 \mathrm{X}_{1}+ \\
0.149 \mathrm{X}_{2}+0.205 \mathrm{X}_{3} \text {. }\end{array}$ & $\begin{array}{c}\mathrm{H}_{0}: \square_{\mathrm{y} .123} £ \\
0 \\
\mathrm{H}_{1}: \\
\square_{\mathrm{y} .123}>0\end{array}$ & 405.087 & $\begin{array}{c}\mathrm{H}_{0} \\
\text { rejected }\end{array}$ & Significant & $\begin{array}{c}0.91 \\
2\end{array}$ & $\begin{array}{c}83.2 \\
\%\end{array}$ \\
\hline
\end{tabular}

The coefficient of determination $\left(R^{2}\right)$ between organizational culture and job satisfaction is $=0.768$. This means that $76.8 \%$ job satisfaction is the result of the interaction of corporate culture while the amount of $23.2 \%$ is contributed by other variables that may be related with the increased job satisfaction. The findings obtained in this study indicate that organizational culture is a set of values that evolves within an organization that helps members of the group take acceptable and unacceptable actions. Lecturers will be encouraged to be innovative and risk-ready, attention to detail, attention to results rather than to techniques and processes used to achieve results, taking into account the impact of results on people in the organization, working on a team rather than on an aggressive basis, competitive and not casual, and maintain the status quo. From the findings obtained in this 2-stage research, it can be seen that the organizational culture is a set of values that develop in an organization that helps members of the organization take action that is acceptable and unacceptable will be able to contribute to improving job satisfaction.

The coefficient of determination between transformational leadership and job satisfaction is $=0.571$. This means that $57.1 \%$ job satisfaction is the result of transformational leadership interaction, while $42.9 \%$ is contributed by other variables that have the relationship with increased job satisfaction. The findings obtained in this study indicate that transformational leadership is the behavior of a leader who directs subordinates to use the values that exist toward today vision and mission set able to contribute to improving job satisfaction.

The coefficient of determination between work motivation and job satisfaction is $=0.556$. This means that $55.6 \%$ job satisfaction is the result of work motivation, while $44.4 \%$ is contributed by other variables that have the relationship with increased job satisfaction. The findings obtained in this study 
indicate that work motivation is a process that directs and encourages activities to achieve organizational goals.

The value of multiple correlation coefficients between organizational culture, transformational leadership, and work motivation together with job satisfaction is 0.912 indicates that any improvement of organizational culture, transformational leadership, and work motivation score together will increase job satisfaction. The results obtained for the coefficient of determination is 0.832 . This means that $83.2 \%$ job satisfaction is the fruit of the workings of organizational culture, transformational leadership and work motivation together, while $16.8 \%$ is contributed by other variables that have a relationship with increased job satisfaction. The findings obtained in this study indicate that if a set of values developed within an organization that helps members of the organization take acceptable and unacceptable actions as well as the behavior of a leader who directs his subordinates to use current values towards the vision and mission which has been established well. It will be able to improve the positive attitude that lecturers have regarding the various aspects of work-related feelings. Thus it can be seen, if a lecturer who has a real perception of organizational culture and has tremendous transformational leadership and is highly motivated together will be able to increase the value of job satisfaction of a lecturer.

Based on the results of interviews with qualitative studies, it can be revealed other than organizational culture, transformational leadership, and work motivation, several factors are considered to be related to job satisfaction, among others: wages or salary received, career development opportunities, employee relations, type of work, organizational structure, lecturer competence and role clarity.

\section{CONCLuSiON}

The findings prove that there is a positive and significant relationship between the organizational culture of lecturers' work satisfaction, transformational leadership on lecturers' work satisfaction and professional motivation on lecturers' work satisfaction among Islamic private universities located in Jambi Indonesia. With particular reference to the initial design of the interaction among variables, the results showed that the contribution of organizational culture variable on lecturers' work satisfaction is $76.8 \%$, transformational leadership is $57.1 \%$, and working motivation is $55.6 \%$ indicating the highest individual contribution to the performance of teachers is organizational culture. When combined, the contribution of the three variables of organizational culture, transformational leadership, and working motivation achieve $83.2 \%$ indicating the contribution of other variables not included in the model to predict lecturers' work satisfaction are only $16.8 \%$.

Based on interviews in the qualitative study it is revealed other factors than organizational culture, transformational leadership, and motivation of teachers associated with lecturers' work satisfaction. Those factors are wages or salary received, career development opportunities, employee relations, type of work, organizational structure, lecturer competence and job clarity

\section{REFERENCES}

[1] Anoraga, Pandji. Psikologi Kerja. Jakarta: Rineka Cipta, 2006.

[2] Bernard M. Bass \& Ronald E. Riggio, Transformational Leadership,(New Jersey: Lawrence Erlbaum associates, Publishers, 2006

[3] Colquitt, J., Lepine, J. A., \& Wesson, M. J., Organizational behavior: Improving performance and commitment in the workplace. McGraw-Hill/Irwin, 2009

[4] Gibson James M., Organizations: Behavior, Structure, Processes, International Edition, New York: Mc Graw-Hill Companies, 2006.

[5] Jason A. Colquit., Jeffery A, Lepine and Michel J Wessor, Organizational Improving Performance and Commitment in the Workplace, (New York McGraw Hill/Irwin, 2009), pp. 546-551

[6] Kreitner, Robert-Angelo Kinicki. Perilaku Organisasi. Terjemahan Suandy Early. Jakarta: Salemba Empat, 2000.

[7] Luthans, Fred. Organizational behavior: An Evidence-Based Approach, Mc Graw-Hill Irwin Companies, 2011. 
[8] Mangkunegara, Anwar Prabu. Manajemen Sumber Daya Manusia Perusahaan. Bandung: Remaja Rosdakarya, 2004.

[9] Schein, Edgar H. Organizational Culture, and Leadership: A Dynamic View. San Francisco: Josey-Bass Publisher, 2004.

[10] Wexley, Kenneth N. dan Gary A. Yuki. Perilaku Organisasi dan Psikologi Personalia. Terjemahan Muh. Shobaruddin. Jakarta: Asdi Mahasatya, 2005.

Citation: Ida Ryanti et al. "The Correlation between Organizational Culture, Transformational Leadership and Work Motivation to Work Satisfaction."International Journal of Managerial Studies and Research (IJMSR), vol 5, no. 9, 2017, pp. 18-23. doi:http://dx. doi.org/10.20431/2349-0349.0509004.

Copyright: (C) 2017 Authors. This is an open-access article distributed under the terms of the Creative Commons Attribution License, which permits unrestricted use, distribution, and reproduction in any medium, provided the original author and source are credited. 